\title{
Phosphorus acquisition and internal utilization efficiency in tropical maize genotypes
}

\author{
Sidney Netto Parentoni(1) and Claudio Lopes de Souza Júnior ${ }^{(2)}$
}

(1)Embrapa Milho e Sorgo, Caixa Postal 151, CEP 35701-970 Sete Lagoas, MG, Brazil. E-mail: sidney@cnpms.embrapa.br (2)Escola Superior de Agricultura Luiz de Queiroz, Departamento de Genética, Caixa Postal 83, CEP 13400-970 Piracicaba, SP, Brazil. E-mail clsouza@esalq.usp.br

\begin{abstract}
The objective of this work was to determine the relative importance of phosphorus acquisition efficiency (PAE - plant P uptake per soil available P), and phosphorus internal utilization efficiency (PUTIL - grain yield per $\mathrm{P}$ uptake) in the P use efficiency (PUE - grain yield per soil available P), on 28 tropical maize genotypes evaluated at three low $\mathrm{P}$ and two high P environments. PAE was almost two times more important than PUTIL to explain the variability observed in PUE, at low $\mathrm{P}$ environments, and three times more important at high $\mathrm{P}$ environments. These results indicate that maize breeding programs, to increase PUE in these environments, should use selection index with higher weights for PAE than for PUTIL. The correlation between these two traits showed no significance at low or at high $\mathrm{P}$ environments, which indicates that selection in one of these traits would not affect the other. The main component of PUTIL was P quotient of utilization (grain yield per grain P) and not the $\mathrm{P}$ harvest index (grain $\mathrm{P}$ per $\mathrm{P}$ uptake). Selection to reduce grain $\mathrm{P}$ concentration should increase the quotient of utilization and consequently increase PUTIL.
\end{abstract}

Index terms: Zea mays, mineral nutrition, phosphorus acquisition, phosphorus use efficiency, plant breeding, quotient of utilization.

\section{Eficiência de aquisição e utilização interna de fósforo em genótipos tropicais de milho}

\begin{abstract}
Resumo - O objetivo deste trabalho foi determinar a importância relativa da eficiência de aquisição (EAP - P absorvido por unidade de P no solo) e de utilização interna de fósforo (EUIP - produção de grãos por unidade de P absorvido), sobre a eficiência de uso desse nutriente (EUP - produção de grãos por unidade de P no solo), em 28 genótipos tropicais de milho, avaliados em três ambientes com baixa e dois com alta disponibilidade de $\mathrm{P}$. A eficiência de aquisição de $P$ foi quase duas vezes mais importante que a EUIP, na variabilidade observada em EUP, nos ambientes com baixa disponibilidade de P, e três vezes mais importante naqueles com alta disponibilidade. Programas de melhoramento de milho devem utilizar índices de seleção com peso maior para EAP do que para EUIP, para aumento na EUP. A correlação entre EAP e EUIP não foi significativa em nenhum dos níveis de P. A seleção numa dessas características, portanto, não deve afetar a outra. O principal componente da EUIP foi o quociente de utilização (produção de grãos por unidade de $\mathrm{P}$ nos grãos), e não o índice de colheita de $\mathrm{P}$ (P nos grãos por unidade de $\mathrm{P}$ absorvido). A seleção para reduzir a concentração de $\mathrm{P}$ nos grãos deve aumentar o quociente de utilização e conseqüentemente aumentar a EUIP.
\end{abstract}

Termos para indexação: Zea mays, nutrição mineral, aquisição de fósforo, eficiência de uso de fósforo, melhoramento de plantas, quociente de utilização.

\section{Introduction}

Phosphorus is the world's second largest consumed nutrient in agriculture, and is surpassed only by nitrogen (Batten, 1992). The nonrenewable phosphate reserves in the world, which could be exploited at values of 40 dollars per $\mathrm{Mg}$, should be exhausted in the second half of this century (Murrel \& Fixen, 2006), indicating that research aimed at developing P efficient plants will exert a pivotal role for agriculture in the coming years.

Grain phosphorus is stored mainly as the anti-nutritional factor phytic acid (Raboy, 2001). The use of large doses of $\mathrm{P}$ fertilizer is not normally within the economic reach of small farmers in developing countries, and the disposal of high-P manure from livestock production units can lead to water source contaminations (Wardyn \& Russel, 
2004). The development of maize cultivars with higher $P$ use efficiency would provide an ecologically acceptable and relatively inexpensive solution to these problems (Good et al., 2004).

Efficiency concepts in plant mineral nutrition have been defined based on the process by which plants acquire, transport, store and use the nutrient in order to produce dry matter or grain, at low or high nutrient supply (Ciarelli et al., 1998). The concepts of nutrient acquisition efficiency, used in the sense of plant nutrient acquired from the soil, and nutrient internal utilization efficiency, defined as plant internal ability to produce yield units per unit of nutrient in the plant, have been considered as the two major components of plant nutrient use efficiency (Good et al., 2004).

A higher $\mathrm{P}$ use efficiency in plants has been achieved by improving both components: $\mathrm{P}$ acquisition and $\mathrm{P}$ internal utilization efficiency. The main mechanisms related to increased $\mathrm{P}$ acquisition efficiency are: root morphology and architecture, which is based on the increase in root volume and area; the genotype ability to associate with soil rhizosphere microorganisms (micorrhyzae, bacteria and fungi), which would facilitate soil $\mathrm{P}$ acquisition; and the genotype capacity to secrete organic compounds in the rhizosphere (like phosphatases and organic acids), which would release $\mathrm{P}$ from organic or inorganic soil sources. A higher P internal utilization efficiency has been attributed to a higher grain yield per unit of $\mathrm{P}$ in the grain (quotient of utilization) and to a higher ability to transfer nutrient from shoot to grains, called P harvest index (Baligar \& Fageria, 1997).

Moll et al. (1982) proposed a methodology to determine the relative importance of two variables (A and $\mathrm{B}$ ), over a third one (C), which was obtained from the product of the first two variables $(C=A B)$. They used a $\log$ transformation to obtain an additive relationship between these variables $(\log C=\log A+\log B)$ and determined the proportion of the sum of squares of $C$, which was due to A and B. These authors used this approach to investigate the relative importance of nitrogen $(\mathrm{N})$ acquisition and internal utilization efficiency over $\mathrm{N}$ use efficiency, in a group of eight maize hybrids evaluated under high and low N supply. Moll et al. (1982) observed that, in the set of environments and genotypes studied, $\mathrm{N}$ use efficiency was mainly a function of $\mathrm{N}$ acquisition efficiency at high $\mathrm{N}$ soils while, at low $\mathrm{N}$ soils, $\mathrm{N}$ efficiency was mainly related to $\mathrm{N}$ internal utilization efficiency.
The relative importance of nutrient acquisition and internal utilization efficiency over nutrient use efficiency has varied in different studies, according to the crop and method of evaluation used (field, greenhouse nutrient solution, or pot experiments). Higher importance of $\mathrm{N}$ internal utilization efficiency than $\mathrm{N}$ acquisition efficiency has been reported in oats (Isfan, 1993). The highest importance of $\mathrm{P}$ acquisition efficiency has been reported in maize nutrient solution studies (Furlani et al., 1985) and in pot experiments with green pepper (Oliveira et al., 1999).

A better knowledge of the relative importance of $\mathrm{P}$ acquisition and internal utilization efficiency would have implications in areas such as: plant physiology - to prioritize studies in mechanisms of nutrient acquisition or utilization; plant breeding - establishment of selection indexes including different nutrient efficiency selection criteria; and QTL mapping studies - choice of traits to be mapped.

The objective of this work was to determine the relative importance of $\mathrm{P}$ acquisition and internal utilization in the $\mathrm{P}$ use efficiency, in 28 tropical maize genotypes, evaluated under high and low $\mathrm{P}$ environments.

\section{Materials and Methods}

A group of 47 maize genotypes were evaluated in five field experiments at Embrapa Milho e Sorgo, in Brazil ( $19^{\circ} 27^{\prime} \mathrm{S}, 716 \mathrm{~m}$ of altitude), during the summer seasons of 2004/2005 (two trials) and 2005/2006 (three trials). These genotypes comprised six inbred lines with contrasting $\mathrm{P}$ use efficiency such as: a P highly efficient line (L3); an efficient line (228-3); a median efficient line (L36); and three P inefficient lines (L22, L53 and Cateto). All inbred lines were developed by Embrapa's maize breeding program. Seven $F_{1}$ crosses were used in this study: four crosses between a highly efficient or an efficient line and an inefficient one (L3 $553, \mathrm{~L} 3 \times 22$, L3xCateto and 228-3xL22); one cross between a highly efficient and a median efficient line (L3xL36); one cross between a median efficient and an inefficient line (L36xCateto), and one cross between two inefficient lines (Cateto x 53). During the years 2003 and 2004, the generations $\mathrm{F}_{2}$, back-cross one to each parent $\left(\mathrm{BC}_{1} \mathrm{P}_{1}\right.$ and $\left.\mathrm{BC}_{1} \mathrm{P}_{2}\right)$ and back-cross two to each parent $\left(\mathrm{BC}_{2} \mathrm{P}_{1}\right.$ and $\left.\mathrm{BC}_{2} \mathrm{P}_{2}\right)$ were obtained for each cross. A minimum of 50 ears was harvested for each generation in each cross, and a balance-bulked sample of these 
ears was used to represent each generation. Generation $\mathrm{BC}_{2} \mathrm{P}_{2}$ for the cross L3xL22 did not yield enough seed; so it was not included in further studies. A total of 47 treatments was obtained corresponding to six parental lines, seven $F_{1}$, seven $F_{2}$, seven $B_{1} P_{1}$, seven $B_{1} P_{2}$, seven $\mathrm{BC}_{2} \mathrm{P}_{1}$ and six $\mathrm{BC}_{2} \mathrm{P}_{2}$ (due to the missing $\mathrm{BC}_{2} \mathrm{P}_{2}$ for the cross $\mathrm{L} 3 \mathrm{x} 22$ ).

Data from generations $\mathrm{F}_{1}, \mathrm{~F}_{2}, \mathrm{BC}_{1} \mathrm{P}_{1}$ and $\mathrm{BC}_{1} \mathrm{P}_{2}$ in each environment were used to study the relative importance of different efficiency components (Moll et al., 1982). Data from inbred lines and $\mathrm{BC}_{2}$ were not included in these analyses, due to the high inbreeding coefficient of these generations, associated with the fact that dominance effects were important in the traits studied. A total of 28 treatments $-7 \mathrm{~F}_{1}, 7 \mathrm{~F}_{2}, 7 \mathrm{BC}_{1} \mathrm{P}_{1}$ and $7 \mathrm{BC}_{1} \mathrm{P}_{2}$ - was used in this study.

The experimental design was with randomized complete blocks with tree replicates in each environment. A two-row plot, $3 \mathrm{~m}$ long and $0.80 \mathrm{~m}$ apart, was used for each generation, except for the $F_{2}$, where a four-row plot was used. Thirty seeds were planted in each row and thinned to 15 plants per row. At maturity, the mean stand in the environments under high $\mathrm{P}$ was 27.3 plants per plot $\left(56,875\right.$ plants ha $\left.^{-1}\right)$; under low $\mathrm{P}$, the mean was 23.2 plants per plot $\left(48,333\right.$ plants $\left.\mathrm{ha}^{-1}\right)$. Border rows were used to separate the inbred lines from other generations.

The soil used was a clayed Rhodic Haplustox ["Latossolo Vermelho", Embrapa (2006)] under savanna vegetation, with contrasting $P$ levels evaluated using the Mehlich 1 extractor. In the 2004/2005 season, an area with high P (named High P-01) and an area with low P (Low P-01) were used. In the season of 2005/2006, an area with high P (named High P-02) and two areas with low P (Low P-02 and Low P-03) were used. The three low $\mathrm{P}$ areas had soil $\mathrm{pH}$ values from 4.7 to 5.4 , and the two high $\mathrm{P}$ areas had $\mathrm{pH}$ values of 5.8 and 5.5. The soil available $P$ in the three low $P$ areas, at $0-20 \mathrm{~cm}$ and 20-60 cm was: low P-01, 4.4 and $2 \mathrm{mg} \mathrm{kg}^{-1}$; low P-02, 7.4 and $2.7 \mathrm{mg} \mathrm{kg}^{-1}$; low P-03, 6.3 and $3 \mathrm{mg} \mathrm{kg}^{-1}$, respectively. Soil bulk density in these areas was $1 \mathrm{~kg} \mathrm{dm}^{-3}$. Based on soil analyses and on soil bulk density, total available $\mathrm{P}$ in the $0-60 \mathrm{~cm}$ layer $(\mathrm{Ps})$, for low $\mathrm{P}$ areas one to three, was $16.8,25.8$ and $24.8 \mathrm{~kg} \mathrm{ha}^{-1}$, respectively. For the two high $\mathrm{P}$ areas, the available $\mathrm{P}$ at $0-20 \mathrm{~cm}$ and 20-60 cm deep was: high P-01 (15.31 and $2.81 \mathrm{mg} \mathrm{kg}^{-1}$ ) and high P-02 (16 and $3 \mathrm{mg} \mathrm{kg}^{-1}$ ), corresponding to 41.9 and $44 \mathrm{~kg} \mathrm{ha}^{-1}$ of total available $\mathrm{P}$ in the soil, respectively. In all five areas, $20 \mathrm{~kg} \mathrm{ha}^{-1}$ of N and $60 \mathrm{~kg} \mathrm{ha}^{-1}$ of $\mathrm{K}_{2} \mathrm{O}$ were applied at sowing. The two high $\mathrm{P}$ areas also received $200 \mathrm{~kg} \mathrm{ha}^{-1}$ of triple superphosphate at planting, corresponding to $39.3 \mathrm{~kg} \mathrm{ha}^{-1}$ of P. Thirty days after sowing, $90 \mathrm{~kg} \mathrm{ha}^{-1}$ of $\mathrm{N}$ were applied as urea. Irrigation was provided at all sites as needed.

The following variables were determined experimentally, for each treatment, in each of the five field trials: available soil P (Ps) from 0-60 cm; grain dry matter yield (Gr) and stove dry matter yield (Sto); grain $\mathrm{P}$ concentration (GPc) and stove $\mathrm{P}$ concentration $(\mathrm{SPc})$; grain $\mathrm{P}$ content $(\mathrm{Pg})$, in which $\mathrm{Pg}=\mathrm{Gr} \times \mathrm{GPc}$; stove $\mathrm{P}$ content $(\mathrm{Pso})$, in which Pso $=$ Sto $\mathrm{x} \mathrm{SPc}$; total $\mathrm{P}$ content (Pt) of plant shoot, in which, $\mathrm{Pt}=\mathrm{Pg}+\mathrm{Pso}$. To determine stove and grain $\mathrm{P}$ concentrations, stove from five plants and $200 \mathrm{~g}$ of grains were sampled from each plot. These samples were oven-dried at $65^{\circ} \mathrm{C}$, and grain and stove dry matter were determined. Grain and stove samples were ground and digested in a 2:1 solution of nitric and percloric acid. Phosphorus concentration was determined by the colorimetric blue molybdenum spectrophotometer method (Silva, 1999).

Two groups of efficiency variables were obtained from the adjusted means of each treatment in each environment. The first group comprised the variables $\mathrm{P}$ acquisition efficiency (PAE) and $\mathrm{P}$ internal utilization efficiency (PUTIL), which were used to obtain the $P$ use efficiency (PUE), as follows: $\mathrm{PAE}=\mathrm{Pt} / \mathrm{Ps}(\mathrm{kg}$ of $\mathrm{P}$ in the plant per $\mathrm{kg}$ of soil available P); and PUTIL $=\mathrm{Gr} / \mathrm{Pt}$ ( $\mathrm{kg}$ of grain dry matter produced per $\mathrm{kg}$ of $\mathrm{P}$ in the plant).

Phosphorus use efficiency (Gr/Ps) was obtained for each treatment in each environment, by multiplying the means of PAE and PUTIL.

The second group comprised the two variables, quotient of utilization and $\mathrm{P}$ harvest index, also used to obtain the variable PUTIL, as follows: quotient of $\mathrm{P}$ utilization $($ QUTIL) $=\mathrm{Gr} / \mathrm{Pg}$ ( $\mathrm{kg}$ of grain dry matter per $\mathrm{kg}$ of $\mathrm{P}$ in the grain); and $\mathrm{P}$ harvest index $(\mathrm{PHI})=\mathrm{Pg} / \mathrm{Pt}(\mathrm{kg}$ of grain $\mathrm{P}$ per $\mathrm{kg}$ of $\mathrm{P}$ in the plant $)$. A new variable $P$ internal utilization efficiency (PUTIL) was obtained for each treatment in each environment, by multiplying the mean of quotient of utilization and $\mathrm{P}$ harvest index.

The model used for ANOVA in each environment, according to Cochran \& Cox (1966), was: $y_{i j}=\mu+t_{i}+$ $r_{j}+e_{i j}$, in which: $y_{i j}$ is the observed value for $i$ treatment at $\mathrm{j}$ replicate; $\mu$ is the general mean; $\mathrm{t}_{\mathrm{i}}$ is the effect of treatment $i(i=1,2, \ldots 47) ; r_{j}$ is the effect of replicate $j$ 
$(j=1,2,3)$; $e_{i j}$ is the experimental error associated to $i$ treatment at $j$ replicate. The software SAS 8.2 for Windows (SAS Institute, 2000) was used for statistical analysis. In each location, the treatment means for the traits grain yield and stove yield were corrected for the mean number of plants per plot using the covariance method (Steel \& Torrie, 1960). The adjusted means from each location were used to obtain combined ANOVA analyses for the three low $\mathrm{P}$, for the two high $\mathrm{P}$ and for all the five environments. For each variable, means for the low and high $\mathrm{P}$ environments were compared using Tukey's test (Pimentel-Gomes, 2000).

The adjusted means from each of the 28 treatments ( $7 \mathrm{~F}_{1}, 7 \mathrm{~F}_{2}, 7 \mathrm{BC}_{1} \mathrm{P}_{1}$ and $7 \mathrm{BC}_{1} \mathrm{P}_{2}$ ), for each of the three low $\mathrm{P}$ environments, were used to obtain the efficiency variables ( $\mathrm{P}$ acquisition efficiency and $\mathrm{P}$ internal utilization efficiency) and the $\mathrm{P}$ internal utilization components (P quotient of utilization and $\mathrm{P}$ harvest index), totaling 84 data points per variable, at low $P$ environments (3 environments and 28 treatments). At high $\mathrm{P}$ environments, a total of 56 data points per variable were used ( 2 environments and 28 treatments per environments).

The relative importance of $\mathrm{P}$ acquisition efficiency and $\mathrm{P}$ internal utilization efficiency in the $\mathrm{P}$ use efficiency was investigated according to Moll et al. (1982). This methodology was developed to investigate the relative importance of two variables (A and B), obtained experimentally, over a third variable (C) which is obtained by the multiplication of A and B. Variables A and B are obtained in a plot mean basis, and the mean of each of these variables - for each treatment, in a given environment - is used to obtain the mean of variable $\mathrm{C}$ for each treatment, at this environment. The relative importance of variable $\mathrm{A}$ and $\mathrm{B}$ over the variability observed in variable $\mathrm{C}$, can be determined as follows: 1) a data logarithm transformation was used to convert the multiplicative relationship $(\mathrm{C}=\mathrm{AB})$ in an additive one, or: $\log (\mathrm{C})=\log (\mathrm{A})+\log (\mathrm{B})-$ the $\log$ transformation was done using the adjusted mean of each genotype in each environment, and transformed variables were renamed as: $\mathrm{Y}=\log (\mathrm{C}), \mathrm{X}_{1}=\log (\mathrm{A})$ and $\mathrm{X}_{2}=\log (\mathrm{B})$; 2 ) the variables $y, x_{1}$ and $x_{2}$ were defined, respectively, as the deviation from the means of $\mathrm{Y}, \mathrm{X}_{1}$ and $\mathrm{X}_{2}$ or: $\left.\mathrm{y}=\mathrm{Y}-\mu ; \mathrm{x}_{1}=\mathrm{X}_{1}-\mu ; \mathrm{x}_{2}=\mathrm{X}_{2}-\mu ; 3\right)$ the sum of squares of variable $\mathrm{Y}\left(\Sigma \mathrm{y}^{2}\right)$ was decomposed into two sums of products: $\Sigma\left(\mathrm{x}_{1} * \mathrm{y}\right)$ and $\left.\Sigma\left(\mathrm{x}_{2} * \mathrm{y}\right) ; 4\right)$ the relative importance of variable $X_{1}$ over variable $Y$ is equal to the proportion of the sum of squares of $Y$ attributable to $X_{1}$, as follows: $\Sigma\left(\mathrm{x}_{1} * \mathrm{y}\right) / \Sigma \mathrm{y}^{2}$. In the same way, the relative importance of variable $\mathrm{X}_{2}$ over variable $\mathrm{Y}$ is equal to: $\left.\Sigma\left(\mathrm{x}_{2} * \mathrm{y}\right) / \Sigma \mathrm{y}^{2} ; 5\right)$ the relative importance of variable $\mathrm{X}_{1}$ over variable $\mathrm{Y}$ is a function of the product of two quantities: a) the coefficient of correlation between variable $\left(\mathrm{x}_{1}\right)$ and $(\mathrm{y})$ or $\mathrm{r}_{\mathrm{x}_{1} \mathrm{y}}$; b) the ratio of the standard deviation of $\mathrm{x}_{1}$ and $\mathrm{y}\left(\mathrm{S}_{\mathrm{x}_{1}} / \mathrm{S}_{\mathrm{y}}\right)$, which can be written as: $\Sigma\left(\mathrm{x}_{1} * \mathrm{y}\right) / \Sigma \mathrm{y}^{2}=\left(\mathrm{r}_{\mathrm{x}_{1} \mathrm{y}}\right) \mathrm{x}\left(\mathrm{S}_{\mathrm{x}_{1}} / \mathrm{S}_{\mathrm{y}}\right)$.

The relative importance of variable $X_{2}$ over variable $\mathrm{Y}$ is a function of the product of the correlation between $\mathrm{X}_{2}$ and $\mathrm{Y}$, multiplied by the ratio of their standard deviations or: $\Sigma\left(\mathrm{x}_{2} * \mathrm{y}\right) / \Sigma \mathrm{y}^{2}=\left(\mathrm{r}_{\mathrm{x}_{2} \mathrm{y}}\right) \mathrm{x}\left(\mathrm{S}_{\mathrm{x}_{2}} / \mathrm{S}_{\mathrm{y}}\right)$.

The described methodology was used to determine the relative importance of $\mathrm{P}$ acquisition efficiency (variable $\mathrm{A}$ ) and $\mathrm{P}$ internal utilization efficiency (variable $\mathrm{B}$ ), in the $\mathrm{P}$ use efficiency (variable $\mathrm{C}$, in which $\mathrm{C}=\mathrm{AB}$ ). In the same way, the relative importance of the $\mathrm{P}$ quotient of utilization (variable $\mathrm{D}$ ) and the $\mathrm{P}$ harvest index (variable $\mathrm{E}$ ), in the $\mathrm{P}$ internal utilization efficiency (variable $\mathrm{B}$, in which $\mathrm{B}=\mathrm{DxE}$ ), was determined. These information could be valuable to establish weights for each of the two variables (P acquisition and $\mathrm{P}$ internal utilization efficiency), in a selection index to be used in breeding programs related to $P$ use efficiency. The same should be done for the two variables related to $P$ internal utilization efficiency (quotient of utilization and $\mathrm{P}$ harvest index).

\section{Results and Discussion}

A mean yield reduction of $47 \%$ was observed from high $\mathrm{P}$ to low $\mathrm{P}$ environments (Table 1). Mean yield reduction of $43 \%$ in maize genotypes from high to low $\mathrm{P}$ environments was reported by Kliemann \& Lima (2001).

Significant differences between high and low P environments were also verified for stove yield, grain $\mathrm{P}$ concentration, $\mathrm{P}$ acquisition efficiency (PAE), $\mathrm{P}$ internal utilization efficiency (PUTIL) and quotient of utilization (QUTIL). The traits stove $\mathrm{P}$ concentration and $\mathrm{P}$ harvest index (PHI) did not differ between high and low $\mathrm{P}$ environments. Higher PUTIL under low P compared to high $\mathrm{P}$ environments has been reported in maize (Resende et al., 2006).

In both combined ANOVA - one for the two high $\mathrm{P}$ and another for the three low P environments -, genotype $\mathrm{x}$ environment interactions were not significant for PAE and PUTIL. Therefore, within each P level of these variables (high and low), treatments were affected in the same way by the group of environments or, treatment 
means constitute a similar group of means to be used in further analysis. However, a significant genotype $\mathrm{x}$ environment interaction was found for both variables in the combined ANOVA, in all the five environments, which indicates that the tested germplasm behaved differently at low and high P levels in the soil (Parentoni, 2008).

Higher PAE and PUTIL efficiency were observed more often in the $\mathrm{F}_{1}$ and $\mathrm{BC}_{1} \mathrm{P}_{1}$ than in the $\mathrm{F}_{2}$ and $\mathrm{BC}_{1} \mathrm{P}_{2}$ (Figure 1). A higher variability between genotypes was observed for PAE than for PUTIL, in both low and high $\mathrm{P}$ environments, as confirmed by the higher ratio of standard deviation verified for PAE than for PUTIL, at low and at high $\mathrm{P}$ environments (Table 2).

No correlation was found between PAE and PUTIL at low $(r=0.201)$ or at high $(r=-0.176)$ P environments, as shown by data dispersion on Figure 1, which indicates that these two variables are independent. Lack of correlation between nitrogen acquisition and nitrogen internal utilization efficiency has been reported in wheat and triticale (Anderson, 1985).

The relative importance of the two components of the $\mathrm{P}$ use efficiency (acquisition and internal utilization), based on Moll et al. (1982) methodology, is shown on Table 2. The genotypes sum of squares for $\mathrm{P}$ use efficiency, under low and high Penvironments, was 2.699 and 0.889 , respectively. The decomposition of each of these sums of squares into the two sum of products showed that, at low P environments, the value of 2.699 is a function of a sum of products due to PAE of 1.742, and a sum of products due to PUTIL of 0.957, indicating that, at low P environments, PAE accounts for $64.5 \%$ of the variability observed in the genotypes, for $\mathrm{P}$ use efficiency, and PUTIL accounts for $35.5 \%$ of this variability. At high P environments, PAE accounts for $74 \%$ of the variability observed for P use efficiency, and PUTIL accounts for $26 \%$ of this variability. A better understanding of these relationships can be achieved based on the correlation coefficients and in the ratio of the variability observed between each $\mathrm{P}$ efficiency component (acquisition and utilization), with $\mathrm{P}$ use efficiency (Table 2). For the low $\mathrm{P}$ environments, the $64.5 \%$ of the variability in $\mathrm{P}$ use efficiency explained by $\mathrm{PAE}$ is a function of its high correlation with $\mathrm{P}$ use efficiency $\left(\mathrm{r}=0.862^{* *}\right)$ and a large ratio of standard deviation between them $(0.748)$ or $0.862 \times 0.748=0.645$. The fact that PUTIL at low soil P explained only $35.5 \%$ of the variability observed in P use efficiency is due to a lower correlation between these two variables $\left(\mathrm{r}=0.683^{* *}\right)$ and a lower variability for $\mathrm{P}$ internal utilization efficiency (0.519).

Similar trend was observed at high P environments, where PAE explained $74 \%$ of the variability observed in P use efficiency (Table 2). This is a function of a high correlation between these variables $\left(\mathrm{r}=0.813^{* *}\right)$ multiplied by a large ratio of standard deviation between them (0.910). The fact that PUTIL at high $\mathrm{P}$ environments explained only $26 \%$ of the variability observed in $\mathrm{P}$ use efficiency is a function of a lower correlation between these two variables $(r=0.441 * *)$ and a lower standard deviation ratio (0.591).

These results indicated that, in the set of genotypes and environments studied, PAE is almost two times more important than PUTIL, at low P environments, and three times more important, at high P environments, to explain the P use efficiency. Physiological studies on P use efficiency in these genotypes, therefore, should give greater attention into understanding of the mechanisms

Table 1. Grain and stove yield means $\left(\mathrm{Mg} \mathrm{ha}^{-1}\right)$, grain and stove $\mathrm{P}$ concentrations (\%), $\mathrm{P}$ acquisition efficiency (PAE, $\left.\mathrm{kg} \mathrm{kg}^{-1}\right)$, P internal utilization efficiency (PUTIL, $\mathrm{kg} \mathrm{kg}^{-1}$ ), P quotient of utilization (QUTIL, $\mathrm{kg} \mathrm{kg}^{-1}$ ) and $\mathrm{P}$ harvest index (PHI, $\mathrm{kg} \mathrm{kg}^{-1}$ ), for 47 maize genotypes evaluated at low and high $\mathrm{P}$ bioavailability environments ${ }^{(1)}$.

\begin{tabular}{|c|c|c|c|c|c|c|c|c|c|}
\hline Environment $^{(2)}$ & Year & $\begin{array}{l}\text { Grain } \\
\text { yield }\end{array}$ & $\begin{array}{l}\text { Stove } \\
\text { yield }\end{array}$ & $\begin{array}{c}\text { Grain } \\
\mathrm{P}\end{array}$ & $\begin{array}{c}\text { Stove } \\
\mathrm{P}\end{array}$ & PAE & PUTIL & QUTIL & PHI \\
\hline High P-01 & 2005 & 4.39 & 8.94 & 0.22 & 0.07 & 0.17 & 284 & 538 & 0.60 \\
\hline High P-02 & 2006 & 5.65 & 7.30 & 0.29 & 0.07 & 0.22 & 261 & 396 & 0.75 \\
\hline Means & & $5.02 \mathrm{a}$ & $8.12 \mathrm{a}$ & $0.26 \mathrm{a}$ & $0.07 \mathrm{a}$ & $0.19 b$ & $273 b$ & $467 \mathrm{~b}$ & $0.68 \mathrm{a}$ \\
\hline Low P-01 & 2005 & 2.29 & 4.31 & 0.19 & 0.06 & 0.33 & 333 & 620 & 0.59 \\
\hline Low P-02 & 2006 & 2.82 & 2.99 & 0.26 & 0.08 & 0.32 & 283 & 433 & 0.72 \\
\hline Low P-03 & 2006 & 2.86 & 3.75 & 0.26 & 0.07 & 0.35 & 278 & 446 & 0.68 \\
\hline Means & & $2.66 \mathrm{~b}$ & $3.68 \mathrm{~b}$ & $0.24 b$ & $0.07 \mathrm{a}$ & $0.33 \mathrm{a}$ & $298 \mathrm{a}$ & $500 \mathrm{a}$ & $0.67 \mathrm{a}$ \\
\hline
\end{tabular}

${ }^{(1)}$ Means followed by the same letters, in the column, do not differ by Tukey test, at $1 \%$ probability. ${ }^{(2)} \mathrm{P}$ bioavailability $\left(\mathrm{kg}\right.$ ha ${ }^{-1}$ of $\mathrm{P}$ from $\left.0-60 \mathrm{~cm}\right)$, for each environment, was: high P-01: 81.2; high P-02: 83.3; low P-01: 16.8; low P-02: 25.8; low P-03: 24.8. 
related to $\mathrm{P}$ acquisition efficiency than mechanisms related to $\mathrm{P}$ internal utilization.

Higher importance of PAE in the P use efficiency, at low or high $\mathrm{P}$ level in the soil, has also been reported in wheat (Manske et al., 2001). These authors found that
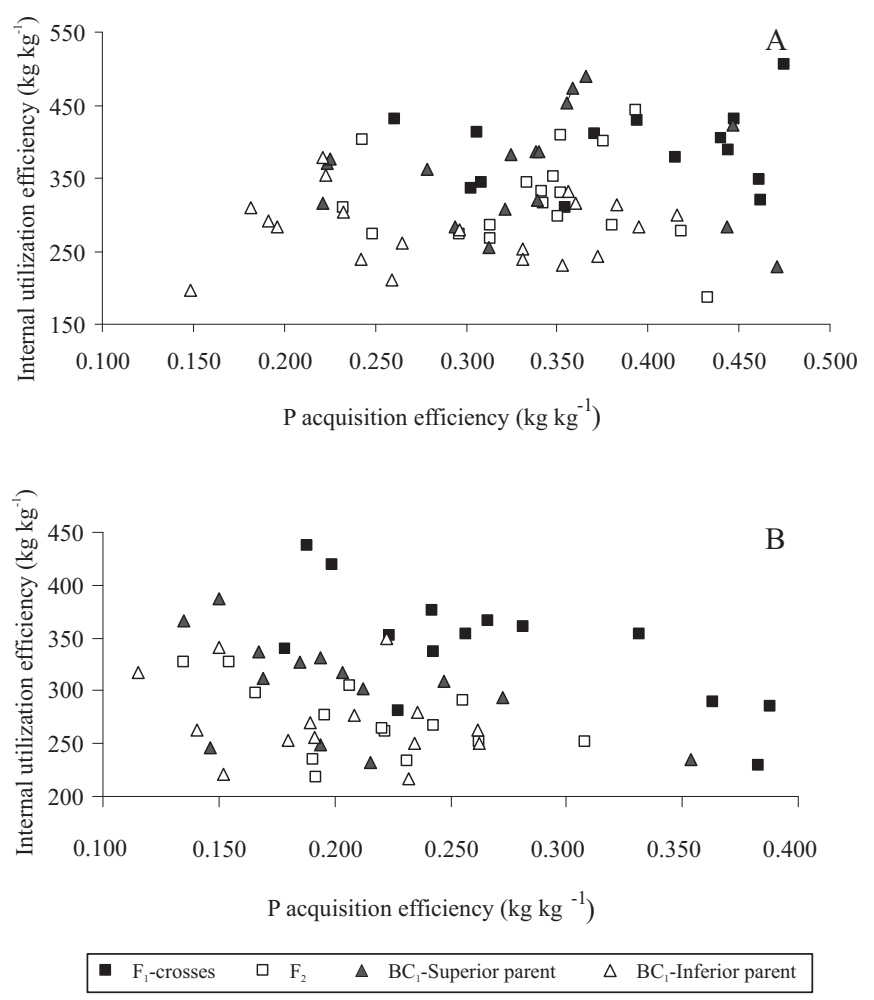

Figure 1. Phosphorus acquisition and Putilization efficiency, in each of three low $\mathrm{P}(\mathrm{A})$ and in two high $\mathrm{P}$ environments (B), for 28 maize genotypes obtained from seven $F_{1}$ crosses and its $\mathrm{F}_{2}$ generations, back-crosses to the superior parent $\left(\mathrm{BC}_{1} \mathrm{P}_{1}\right)$ and back-crosses to the inferior parent $\left(\mathrm{BC}_{1} \mathrm{P}_{2}\right)$.
94 and $100 \%$ of the variability observed in P use efficiency in wheat was due to PAE, in two years of evaluation in a low $\mathrm{P}$ acid soil, and 85 and $95 \%$, in each of two years of evaluation, in a high $\mathrm{P}$ acid soil. For calcareous soil, these authors reported values somewhat lower than the ones found in acid soil ( 0.71 to $0.91 \%$ at low $\mathrm{P}$ and 0.50 to $0.57 \%$ at high $\mathrm{P}$ in the soil), indicating that, soil type should influence the relative importance of $P$ acquisition and internal utilization efficiency in the $P$ use efficiency of crops.

Investigation on root morphology of two maize inbred lines, used as parents in the present study (L3 and L22), conducted under low and high $\mathrm{P}$ conditions, showed that the $\mathrm{P}$ efficient line $\mathrm{L} 3 \mathrm{~h}$ had a higher $\mathrm{P}$ acquisition ability and a larger and deeper root system than the $P$ inefficient line L22 (Brasil, 2003). Oliveira et al. (2008), who isolated $\mathrm{P}$ solubilizing microorganisms from the rhizosphere of inbred lines L3 and L22 and from two other unrelated maize single crosses, observed that the highest P solubilizing microorganism Bulkhoderia sp. was isolated from the rhizosphere of inbred line L3, being capable of solubilizing $70 \%$ of insoluble P-Ca supplied in the medium. These previous findings indicate that the higher $P$ acquisition efficiency in genotypes derived from the inbred line L3 should be either related to root morphological traits (Brasil, 2003) or to a higher capacity to associate with $\mathrm{P}$ solubilizing microorganism in the rhizosphere, especially Bulkhoderia sp. (Oliveira et al., 2008).

Corrales et al. (2007) reported that the single cross (L3x228-3), obtained from the two efficient inbreds used as parents in the present study showed higher P use efficiency than a P inefficient hybrid, in a medium with sand and sparingly soluble rock phosphate. This was

Table 2. Contribution of genotypes sum of squares (SS) from $\mathrm{P}$ acquisition efficiency $\left(\mathrm{X}_{1}\right)$ and $\mathrm{P}$ internal utilization efficiency $\left(\mathrm{X}_{2}\right)$ to the sum of squares of $\mathrm{P}$ use efficiency $(\mathrm{Y})$, correlation between $\mathrm{X}_{\mathrm{i}}$ and $\mathrm{Y}\left(\mathrm{r}_{\mathrm{xiy}}\right)$ and standard deviation ratio between $\mathrm{X}_{\mathrm{i}}$ and $\mathrm{Y}\left(\mathrm{S}_{\mathrm{x}_{\mathrm{i}}} / \mathrm{S}_{\mathrm{y}}\right)$, at three low $\mathrm{P}$ and two high $\mathrm{P}$ environments.

\begin{tabular}{lccr}
\hline Trait & $\begin{array}{c}\text { Genotypes } \\
\mathrm{SS}^{(1)}\end{array}$ & $\begin{array}{c}\text { Contribution of } \mathrm{X}_{\mathrm{i}} \text { to the SS of P } \\
\text { use efficiency }(\mathrm{Y})^{(2)}\end{array}$ & $\begin{array}{c}\mathrm{r}_{\mathrm{x}_{\mathrm{i}} \mathrm{y}} \\
\left(\mathrm{S}_{\mathrm{x}_{\mathrm{i}}} / \mathrm{S}_{\mathrm{y}}\right)\end{array}$ \\
\hline P acquisition efficiency $\left(\mathrm{X}_{1}\right)$ & $\begin{array}{c}\text { Three low P environments } \\
\text { P utilization efficiency }\left(\mathrm{X}_{2}\right)\end{array}$ & 0.645 & 0.862 \\
P use efficiency (Y) & 1.742 & 0.355 & 0.748 \\
& 0.957 & Two high P environments & 0.519 \\
P acquisition efficiency $\left(\mathrm{X}_{1}\right)$ & 2.699 & 0.740 & 0.813 \\
P utilization efficiency $\left(\mathrm{X}_{2}\right)$ & 0.658 & 0.260 & 0.910 \\
P use efficiency $(\mathrm{Y})$ & 0.231 & & 0.441 \\
\hline
\end{tabular}

${ }^{(1)}$ Determined by $\Sigma\left(\mathrm{x}_{\mathrm{i}} \mathrm{y}\right) / \Sigma \mathrm{y}^{2}$ in which: $\mathrm{i}=1$ for $\mathrm{P}$ acquisition efficiency and $\mathrm{i}=2$ for $\mathrm{P}$ utilization efficiency. ${ }^{(2)}$ Product of $\mathrm{r}_{\mathrm{x} y \mathrm{y}}$ multiplied by $\mathrm{S}_{\mathrm{x}_{\mathrm{i}}} / \mathrm{S}_{\mathrm{y}}$. 
attributed mainly to the higher capacity of this genotype to acquire $P$ from the medium, which was also associated with a higher citric acid concentration in the rhizosphere, rather than to its enhanced Pinternal utilization efficiency. Results of the present work corroborate the ones reported by Corrales et al. (2007), in which PAE showed higher importance in $\mathrm{P}$ use efficiency than PUTIL, with genotypes related with the maize P efficient lines L3 and L228-3.

The PUTIL of the genotypes was also decomposed into two components: quotient of utilization (QUTIL) and $\mathrm{P}$ harvest index (PHI). A higher variability between genotypes was observed for QUTIL than for PHI (Figure 2), which was confirmed by the higher ratio of standard deviation of QUTIL and PUTIL, compared to the ratio of standard deviation of PHI and PUTIL, at low and high P environments (Table 3).

The QUTIL accounts for the largest fraction of the variability observed in the genotypes for $\mathrm{P}$ internal utilization efficiency, at low $\mathrm{P}(80.8 \%)$ and at high $\mathrm{P}$ environments $(92.5 \%)$, due to a higher correlation coefficient of QUTIL with PUTIL and also to a larger ratio of standard deviation between QUTIL and this trait.
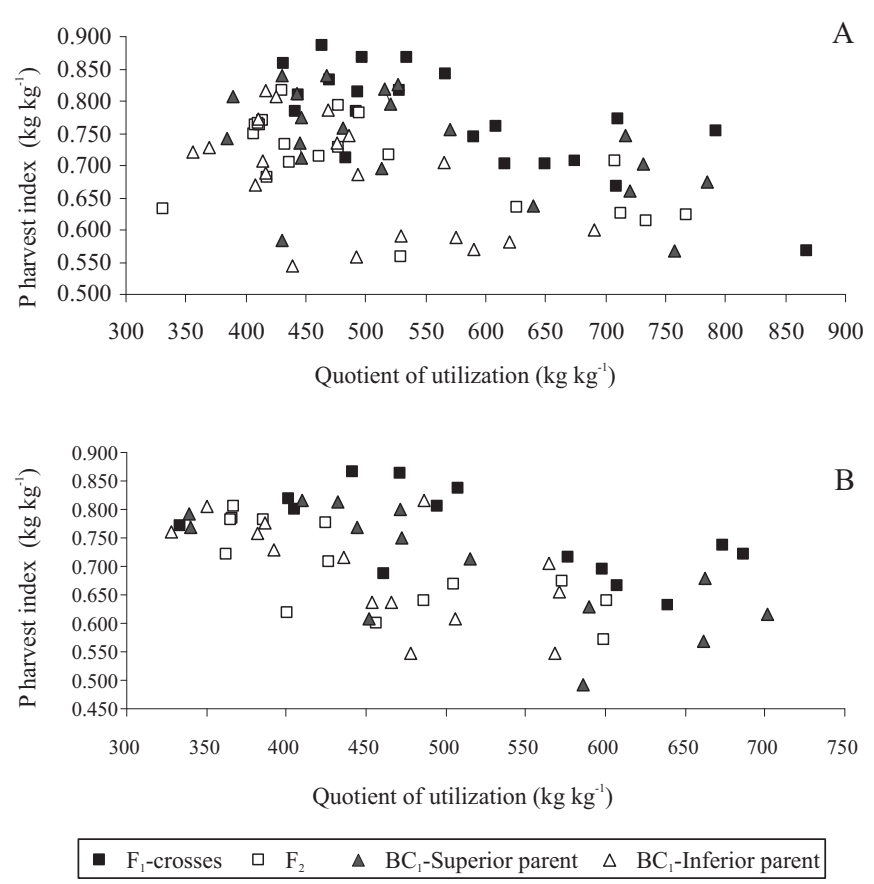

Figure 2. Quotient of utilization and $\mathrm{P}$ harvest index, in each of three low $\mathrm{P}(\mathrm{A})$ and in two high $\mathrm{P}$ environments (B), for 28 maize genotypes obtained from seven $F_{1}$ crosses and its $\mathrm{F}_{2}$ generations, back-crosses to the superior parent $\left(\mathrm{BC}_{1} \mathrm{P}_{1}\right)$ and back-crosses to the inferior parent $\left(\mathrm{BC}_{1} \mathrm{P}_{2}\right)$.
A different situation was verified in wheat (Manske et al., 2001), in which PHI explained 53\% to $82 \%$ of the variability observed for PUTIL, in low and high P environments, respectively. These differences could be a function of the distinct trends in harvest index in maize and wheat. Selection for high yielding cultivars, in the last decades, has had a minor impact in maize harvest index, while a large impact in harvest index has been observed in small cereals, like wheat (Hay, 1995).

As the quotient of utilization is calculated by dividing grain yield per quantity of $\mathrm{P}$ in the grain - which is equal to grain yield multiplied by grain $\mathrm{P}$ concentration -, it corresponds exactly, indeed, to the reciprocal of the grain $\mathrm{P}$ concentration. In this case, the largest is the grain $\mathrm{P}$ concentration, the smallest will be the $\mathrm{P}$ internal utilization efficiency. Selection strategies to increase maize $\mathrm{P}$ internal utilization efficiency in Oxisols should be focused in reducing grain $\mathrm{P}$ concentration, since changes in $\mathrm{P}$ harvest index seems to have a minor contribution to PUTIL in the genotypes and environments studied.

The data reported in this work show that both acquisition and internal utilization efficiency should be considered in a breeding program to increase $\mathrm{P}$ use efficiency, but the higher importance of $\mathrm{P}$ acquisition compared to $\mathrm{P}$ internal utilization efficiency should be taken into account when establishing selection indexes for these traits. The relative weights of these components, in a selection index, could be determined by the fraction of the sum of squares from each $\mathrm{P}$ efficiency component (Table 2). Suggested weights for $\mathrm{P}$ acquisition and for $\mathrm{P}$ utilization efficiency in a selection index would be 0.7 and 0.3 , respectively.

The lack of correlation between $\mathrm{P}$ acquisition and $\mathrm{P}$ utilization efficiency indicates that selection in one of them should not affect the other, which would facilitate simultaneous selection of these traits, in the set of environments studied.

The main selection criteria for $\mathrm{P}$ internal utilization efficiency should be towards reducing the grain $\mathrm{P}$ concentration (inverse of the quotient of utilization) and, in this case, a negative weight should be used in the selection index. Reduction in grain $\mathrm{P}$ concentration would have a positive impact on animal nutrition, since grain $\mathrm{P}$ is stored as the anti-nutritional factor phytate; and it would also reduce environmental pollution from high $\mathrm{P}$ manure produced by large animal feeding lots. However, the strategy of reducing grain $\mathrm{P}$ concentration should have a limit, since grain $\mathrm{P}$ is needed in the grain filling process and it is also important in seed germination. 
Table 3. Contribution of genotypes sum of squares (SS) from $P$ quotient of utilization $\left(X_{1}\right)$ and $P$ harvest index $\left(X_{2}\right)$ to the sum of squares of $\mathrm{P}$ internal utilization efficiency $(\mathrm{Y})$, correlation between $\mathrm{X}_{\mathrm{i}}$ and $\mathrm{Y}\left(\mathrm{r}_{\mathrm{xiy}}\right)$ and standard deviation ratio between $\mathrm{X}_{\mathrm{i}}$ and $\mathrm{Y}\left(\mathrm{S}_{\mathrm{xi}} / \mathrm{S}_{\mathrm{y}}\right)$, at three low $\mathrm{P}$ and two high $\mathrm{P}$ environments.

\begin{tabular}{lccc}
\hline Trait & $\begin{array}{c}\text { Genotypes } \\
\mathrm{SS}^{(1)}\end{array}$ & $\begin{array}{c}\text { Contribution of } \mathrm{X}_{\mathrm{i}} \text { to the SS of } \mathrm{P} \\
\text { internal utilization efficiency }(\mathrm{Y})\end{array}$ & $\begin{array}{c}\mathrm{r}_{\mathrm{x}_{\mathrm{i}} \mathrm{y}} \\
\left(\mathrm{S}_{\mathrm{x}_{\mathrm{i}}} / \mathrm{S}_{\mathrm{y}}\right)\end{array}$ \\
\hline & 0.577 & Three low P environments & 0.793 \\
P quotient of utilization $\left(\mathrm{X}_{1}\right)$ & 0.137 & 0.808 & 0.019 \\
P harvest index $\left(\mathrm{X}_{2}\right)$ & 0.714 & Two high P environments & 0.650 \\
P internal utilization efficiency $(\mathrm{Y})$ & & 0.925 & 0.296 \\
\hline & 0.305 & 0.075 & 0.788 \\
P quotient of utilization $\left(\mathrm{X}_{1}\right)$ & 0.025 & & 0.103 \\
P harvest index $\left(\mathrm{X}_{2}\right)$ & 0.330 & 0.728 \\
P internal utilization efficiency $(\mathrm{Y})$ & & & 0.175 \\
\hline
\end{tabular}

${ }^{(1)}$ Determined by $\Sigma\left(\mathrm{x}_{\mathrm{i}} \mathrm{y}\right) / \Sigma \mathrm{y}^{2}$ in which: $\mathrm{i}=1$ for $\mathrm{P}$ quotient of utilization and $\mathrm{i}=2$ for P harvest index. ${ }^{(2)}$ Product of $\mathrm{r}_{\mathrm{xiy}}$ multiplied by $\mathrm{S}_{\mathrm{xi}} / \mathrm{S}_{\mathrm{y}}$.

\section{Conclusions}

1. Both acquisition and internal utilization efficiency should be considered in a breeding program to increase P use efficiency, but the major component of this trait, in the maize genotypes evaluated under low or high $\mathrm{P}$ environments, is the acquisition efficiency.

2. The absence of correlation between $P$ acquisition efficiency and $\mathrm{P}$ internal utilization efficiency, at low or high $\mathrm{P}$ environments, indicates that selection in one of these variables should not affect the other, in neither environments.

3. In a breeding program to increase $\mathrm{P}$ internal utilization efficiency, a higher importance should be given to the quotient of utilization than to $\mathrm{P}$ harvest index; this should be accomplished by selecting genotypes with lower grain $\mathrm{P}$ concentration.

\section{Acknowledgements}

To Embrapa, for scholarship granted; to McKnight, for financial support to the project; to the field work technicians: Clayton Godoy and Denilson Oliveira.

\section{References}

ANDERSON, W.K. Differences in response of winter cereal varieties to applied nitrogen in the field. II. Some factors associated with differences in response. Field Crops Research, v.11, p.369-385, 1985.

BALIGAR, V.C.; FAGERIA, N.K. Nutrient use efficiency in acid soils: nutrient management and plant use efficiency. In: MONIZ, A.C.; FURLANI, A.M.C.; SCHAFFERT, R.E.; FAGERIA, N.K.; ROSOlEM, C.A.; CANTARELlA, H. (Ed.). Plant-soil interactions at low pH: sustainable agriculture and forestry production. Campinas: Sociedade Brasileira de Ciência do Solo, 1997. p.75-95.
BATTEN, G.D. A review of phosphorus efficiency in wheat. Plant and Soil, v.146, p.163-168, 1992.

BRASIL, E.C. Mecanismos envolvidos na eficiência de aquisição de fósforo em genótipos de milho. 2003. 161p. Tese (Doutorado) - Universidade Federal de Lavras, Lavras.

CIARELLI, D.M.; FURLANI, A.M.C.; DECHEN, A.R.; LIMA, $M$. Genetic variation among maize genotypes for phosphorus-uptake and phosphorus-use efficiency in nutrient solution. Journal of Plant Nutrition, v.21, p.2219-2229, 1998.

COCHRAN, W.G.; COX, G.M. Experimental design. 2.ed. New York: John Wiley, 1966. 611p.

CORRALES, I.; AMENÓS, M.; POSCHENRIEDER, C.; BARCELÓ, J. Phosphorus efficiency and root exudates in two contrasting tropical maize varieties. Journal of Plant Nutrition, v.30, p.887-900, 2007.

EMBRAPA. Sistema brasileiro de classificação de solos. 2.ed. Rio de Janeiro: Embrapa Solos, 2006. 306p.

FURLANI, A.M.C.; BATAGLIA, O.C.; LIMA, M. Eficiência de linhagens de milho na absorção e utilização de fósforo em solução nutritiva. Bragantia, v.44, p.129-147, 1985.

GOOD, A.G.; SHRAWAT, A.K.; MUENCH, D.G. Can less yield more? Is reducing nutrient input into the environment compatible with maintaining crop production? Trends in Plant Science, v.9, p.597-605, 2004.

HAY, R.K.M. Harvest index: a review of its use in plant breeding and crop physiology. Annals of Applied Biology, v.126, p.197216, 1995.

ISFAN, D. Genotypic variability for physiological efficiency index of nitrogen in oats. Plant and Soil, v.154, p.53-59, 1993.

KLIEMANN, H.J.; LIMA, D.V. Eficiência agronômica de fosfatos naturais e sua influência no fósforo disponível em dois solos de Cerrado. Pesquisa Agropecuária Tropical, v.31, p.111-119, 2001. MANSKE, G.G.B.; ORTIZ-MONASTÉRIO, J.I.; van GINKEL, M.; GONZÁLEZ, R.M.; FISCHER, R.A.; RAJARAM, S.; VLEK, P.L.G. Importance of P uptake efficiency versus $P$ utilization for 
wheat yield in acid and calcareous soils in Mexico. European Journal of Agronomy, v.14, p.261-274, 2001.

MOLL, R.H.; KAMPRATH, E.J.; JACKSON, W.A. Analysis and interpretation of factors, which contribute to efficiency of nitrogen utilization. Agronomy Journal, v.74, p.562-564, 1982.

MURREL, T.S.; FIXEN, P.E. Improving fertilizer phosphorus effectiveness: challenges for the future. In: INTERNATIONAL SYMPOSIUM ON PHOSPHORUS DYNAMICS IN THE SOILPLANT CONTINUUM, 3., 2006, Uberlândia. Anais. Sete Lagoas: Embrapa Milho e Sorgo, 2006. p.150-151.

OLIVEIRA, C.A.A.; ALVES, V.M.C.; MARRIEL, I.E.; GOMES, E.A.; SCOTTI, M.R.; CARNEIRO, N.P.; GUIMARÃES, C.T.; SCHAFFERT, R.E.; SÁ, N.M.H. Phosphate solubilizing microorganisms isolated from rhizosphere of maize cultivated in an Oxisol of the Brazilian Cerrado Biome. Soil Biology and Biochemistry, 2008, doi: 10.1016/j.soilbio.2008.01.012.

OLIVEIRA, V.R.; CASALI, V.W.D.; PEREIRA, P.R.G.; CRUZ, C.D.; PIRES, N.M. Tolerância de genótipos de pimentão ao baixo teor de fósforo no solo. Bragantia, v.58, p.125-139, 1999.

PARENTONI, S.N. Estimativa de efeitos gênicos de diversos caracteres relacionados à eficiência e resposta ao fósforo em milho tropical. 2008. 207p. Tese (Doutorado) - Escola Superior de Agricultura Luiz de Queiroz, Piracicaba.
PIMENTEL-GOMES, F. Curso de estatística experimental. 14.ed. Piracicaba: Nobel, 2000. 477p.

RABOY, V. Seeds for a better future: 'low phytate' grains help to overcome malnutrition and reduce pollution. Trends in Plant Science, v.6, p.458-462, 2001.

RESENDE, A.V.; FURTINI NETO, A.E.; ALVES, V.M.C.; MUNIZ, J.A.; CURI, N.; FAQUIN, V.; KIMPARA, D.I.; SANTOS, J.Z.L.; CARNEIRO, L.A. Phosphorus sources and application methods for maize in soil of the Cerrado region. Revista Brasileira de Ciência do Solo, v.30, p.453-456, 2006.

SAS INSTITUTE. SAS: user's guide statistics: release 8.2. Cary: SAS Institute, 2000.

SILVA, F.C. Manual de análises químicas de solos, plantas e fertilizantes. Rio de Janeiro: Embrapa-CNPS; Campinas: Embrapa-CNPTIA, 1999. 370p.

STEEL, R.G.D.; TORRIE, J.H. Principles and procedures of statistics. New York: McGrow-Hill, 1960. 481p.

WARDYN, B.M.; RUSSEL, W.K. Resource allocation in a breeding program for phosphorus concentration in maize grain. Crop Science, v.44, p.753-757, 2004.

Received on December 31, 2007 and accepted on June 6, 2008 